\section{The Suitability of Expanded Shale as an Amendment for Clay Soils}

\author{
John J. Sloan, ${ }^{1}$ \\ Steve W. George, ${ }^{2}$ \\ Wayne A. Mackay, ${ }^{3}$ \\ Phil Colbaugh, ${ }^{3}$ and \\ Sam Feagley ${ }^{2}$
}

Summary. Excessive soil moisture in clay soils can cause poor aeration and adversely affect plant growth. Small

[ 1 to $3 \mathrm{~mm}(0.039$ to 0.118 inches $)$ ] and large [ 3 to $6 \mathrm{~mm}(0.118$ to 0.354 inches)] diameter expanded shales (ExSh), quartz sand, sphagnum peatmoss (SPM), and cottonseed hulls (CH) were evaluated as soil amendments for Austin silty clay soil. A 3inch $(7.6-\mathrm{cm})$ layer of each amendment was incorporated to a depth of 6 inches $(15.2 \mathrm{~cm})$, resulting in a $1: 1$ mixture by volume. Pansies (Viola $\times$ wittrockiana 'Crown Azure Blue') were grown from December to June, followed by scaevola (Scaevola aemula 'New Wonder') from June to November for two growing seasons. Foliage quality and extent of flowering were evaluated biweekly. Pansy root weights and above-ground biomass were quantified at the end of each growing season. None of the amendments significantly affected pansy foliage quality or the number of blooms per plant. Small diameter ExSh and SPM decreased pansy nitrogen content the first year after application, but not the second. During the first growing season, when soils were frequently saturated due to excessive rainfall, pansy root weights were significantly higher in

Texas A\&M University Research and Extension Center-Dallas, 17360 Coit Road, Dallas, TX 75252.

This research was partially supported with funding from Texas Industries, Dallas, Texas. Valuable statistical guidance was provided by Dr. Bill Raun (Oklahoma State University) and Dr. Jim Heitholt (Texas Agricultural Experiment Station)

${ }^{1}$ Assistant professor, Texas Agricultural Experiment Station.

${ }^{2}$ Professor, Texas Cooperative Extension.

${ }^{3}$ Associate professor, Texas Agricultural Experiment Station. soils amended with the small and large diameter ExSh. Large diameter ExSh treatments significantly increased the survival rate of transplanted scaevola plants and also the quality of foliage and percent blossom coverage during both growing seasons. Cottonseed hulls also increased scaevola survival for both growing seasons, but did not consistently improve scaevola foliage quality or bloom coverage. Of the five amendments tested, large diameter ExSh consistently improved overall plant performance more than the other amendments.

$\mathrm{F}$ ine-textured clay soils, such as those in the Blackland region of Texas, present unique problems for maintaining healthy plant growth because they exhibit low permeability to air and water (Puentes et al., 1988). During periods of high soil moisture, such as following rainfall or irrigation, there is a reduction in airfilled pore volume (Grable and Siemer, 1968; Jayawardane and Meyer, 1985). Furthermore, the obstruction of pores by infiltrating water hinders air movement into the soil (Erickson, 1982). When water is added to soil during warm temperatures, oxygen is decreased even further due to increased microbial and root respiration (Hendrix et al., 1988; McAfee et al., 1989). The combined effect of these processes is that soil oxygen levels decrease following water infiltration into the soil (Dowdell et al., 1979; Meek et al., 1983).

Root elongation is directly affected by soil aeration (Voorhees et al., 1975). In the absence of oxygen in the rooting zone, cell elongation ceases within 2 to $3 \mathrm{~min}$ and root tips will start to die if oxygen is not restored within $30 \mathrm{~min}$ (Huck, 1970). If low oxygen conditions persist, such as in water-saturated clay soils, root growth will be stunted and the plant may be more susceptible to disease. Since roots are directly responsible for uptake of water and minerals, which are essential for plant growth and development (Salisbury and Ross, 1985), poor root development will decrease the quantity and quality of above-ground plant foliage. Soil amendments that increase porosity in fine textured soils might improve plant growth and quality.

Urban dwellers living on finetextured clay soils could benefit from soil amendments that improve drainage in their garden and flower beds. Sphagnum peatmoss (SPM) is an organic material composed of partially decomposed sphagnum moss (Sphagnum spp.). It has long been used as a component in container growing mediums and in U.S. Golf Association (USGA) putting greens (Carlson et al., 1998). In sand-based growing media, SPM improved turf quality more than several inorganic amendments (Bigelow et al., 2001), but its ability to improve the quality of flowering plants in clay soil is not documented. Many gardeners intuitively believe that sand will improve drainage in a clay soil. Quartz sand is used to construct golf putting greens (USGA, 1993) and has been investigated as a top dressing for sports fields (Baker and Canaway, 1992). However, little is know of its effect on flowering plants when mixed into a clay textured soil. Cottonseed hulls, a byproduct of the cotton ginning industry, contain relatively high amounts of fiber and some protein and are usually used for cattle feed (Hsu et al., 1987). The coarse-textured characteristic of $\mathrm{CH}$ may increase drainage and aeration when mixed with a claytextured soil. Also, decomposing $\mathrm{CH}$ in the soil may provide a source of nitrogen and micronutrients.

Expanded shale (ExSh) is a lightweight, porous, inorganic material commonly used as an ingredient in cement for construction and road surfacing. It is produced by heating mined shale to a temperature of $1200{ }^{\circ} \mathrm{C}$ $\left(2200^{\circ} \mathrm{F}\right)$. Individual ExSh aggregates are able to absorb water at $380 \mathrm{~kg} \cdot \mathrm{t}^{-1}$ (761 lb/ton), of which over half is readily available to plants (Sloan et al., 2000). The heating process creates calcium and magnesium oxides on the surface of ExSh aggregates, which generate an alkaline $\mathrm{pH}(8$ to 10$)$ when measured in water (Sloan et al., 2000). However, ExSh has a low calcium carbonate equivalent $(<0.5 \%)$ and will not measurably affect the $\mathrm{pH}$ of neutral or calcareous soils. Expanded shale has no significant cation exchange capacity, but the presence of oxides allows it to absorb significant amounts of soluble phosphorus (Sloan et al., 2000 ). Due to its relatively inert chemical nature, ExSh has little direct effect on soil chemical properties. However, it could have indirect effects on soil chemistry and biology by modifying the soil physical environment. 
We hypothesized that ExSh would improve plant growth in clay soils, more so than sand or organic amendments, by increasing soil porosity, thereby increasing internal water drainage and oxygen supply to roots. The objective of this research was to determine the effect of ExSh amendments, sand, SPM and $\mathrm{CH}$, on growth and performance of winter-grown pansies and summer-grown scaevola in a poorly drained clay soil.

\section{Materials and methods}

An Austin silty clay soil (fine-silty, carbonatic, thermic Udorthentic Haplustolls) at the Texas A\&M University Research and Extension Center at Dallas was amended with two diameter sizes of ExSh, quartz sand, SPM, and $\mathrm{CH}$. The experimental design was a randomized complete block comprised of six blocks. Each amendment was applied as a 3 -inch layer on the surface of a $3 \times 3-\mathrm{ft}(91-\mathrm{cm})$ plot and then hand-incorporated with a spade into the upper 3 inches of soil, resulting in approximately 6 inches of 1:1 amended soil by volume. Six treatments were included in the study. Unamended soil served as a control. For the control, 3 inches of native soil from an adjacent area was added to each plot and incorporated in a similar fashion to the other amendments. The primary focus of the study was on a 1to 3-mm small-diameter ExSh aggregate (SSh) and a 3- to 6-mm largediameter ExSh aggregate (LSh) (Texas Industries, Dallas). Sphagnum peatmoss (Sun Gro Horticulture, Inc., Bellevue, Wash.) and coarse quartz sand (ACME Materials, Inc., Allen, Texas) represent two forms of soil amendments frequently added to urban soils to improve tilth and drainage. Cottonseed hulls (Martindale Feed Mill, Valley View, Texas) were also evaluated as a potential soil amendment.

For the next 2 years, 'Crown Azure Blue' pansies were grown in the amended soils from December to June, followed by scaveola 'New Wonder', from June to November. Scaevola is a native Australian plant that typically performs poorly in clay-textured soils (Bhalla and Sweeney 1998; Fischer 1990, 1991; Gerlach 1990). During each respective season, each plot was planted with either four pansy plants or two scaevola plants. Pansy plants were evaluated biweekly by rating foli- age quality on a scale of 1 to 10 , with $\mathrm{l}=$ worst and $\mathrm{l} 0=$ best , and by count ing the number of open blossoms per plant. Scaevola foliage was evaluated in a similar fashion to the pansies, but instead of counting scaevola blossoms, they were ranked on a scale of 0 to 10 , with $0=$ no blossoms and $10=$ maxi mum blossom coverage. Before each planting, a complete fertilizer formulation $(21 \mathrm{~N}-3.1 \mathrm{P}-11.6 \mathrm{~K})$ (Calloway's Premium Lawn Fertilizer, Plano, Texas) was added to each plot at a rate of 200,30 , and $110 \mathrm{~kg} \cdot \mathrm{ha}^{-1}(178,27$, and $98 \mathrm{lb} /$ acre) of N, P, and K, respectively. During the growing season, Peters all-purpose plant food $(20 \mathrm{~N}-$ 8.8P-16.6K; Grace-Sierra Horticultural Products Co., Milpitas, Calif.) was applied once per month at N, P, and $\mathrm{K}$ rates of 28,12 , and $23 \mathrm{~kg} \cdot \mathrm{ha}^{-1}$ $(24.5,10.8$, and $20.2 \mathrm{lb} /$ acre $)$, respectively. Sphagnum peatmoss and $\mathrm{CH}$ also added $\mathrm{N}$ to the soil in amounts of 160 and $180 \mathrm{~kg} \cdot \mathrm{ha}^{-1}$ (140 and 150 lb/acre), respectively. However, with
$\mathrm{C}$ to $\mathrm{N}$ ratios of 60 for SPM and 100 for $\mathrm{CH}$, the $\mathrm{N}$ was not immediately available for plant uptake. Irrigation was applied by hand. The frequency and quantity of irrigation was based on visual observations of soil moisture in the top 3 inches. When irrigation was applied, all plots received approximately the same amount of water.

Pansies were harvested at the end of each growing season to determine above-ground dry matter yield, total $\mathrm{N}$ content, and root weights. Aboveground plant tissue was dried at $60^{\circ} \mathrm{C}$ $\left(140^{\circ} \mathrm{F}\right)$, weighed, and then ground to pass a 40 mesh sieve. Total $\mathrm{N}$ was measured using a micro-kjeldahl acid digestion followed by steam distillation (Bremner, 1996). A the end of each season, the root ball from each plant was extracted from the soil with a straight-tined pitchfork and washed with water to remove soil. During the first year, the original root ball was clearly visible, so only roots extending beyond the original root ball were

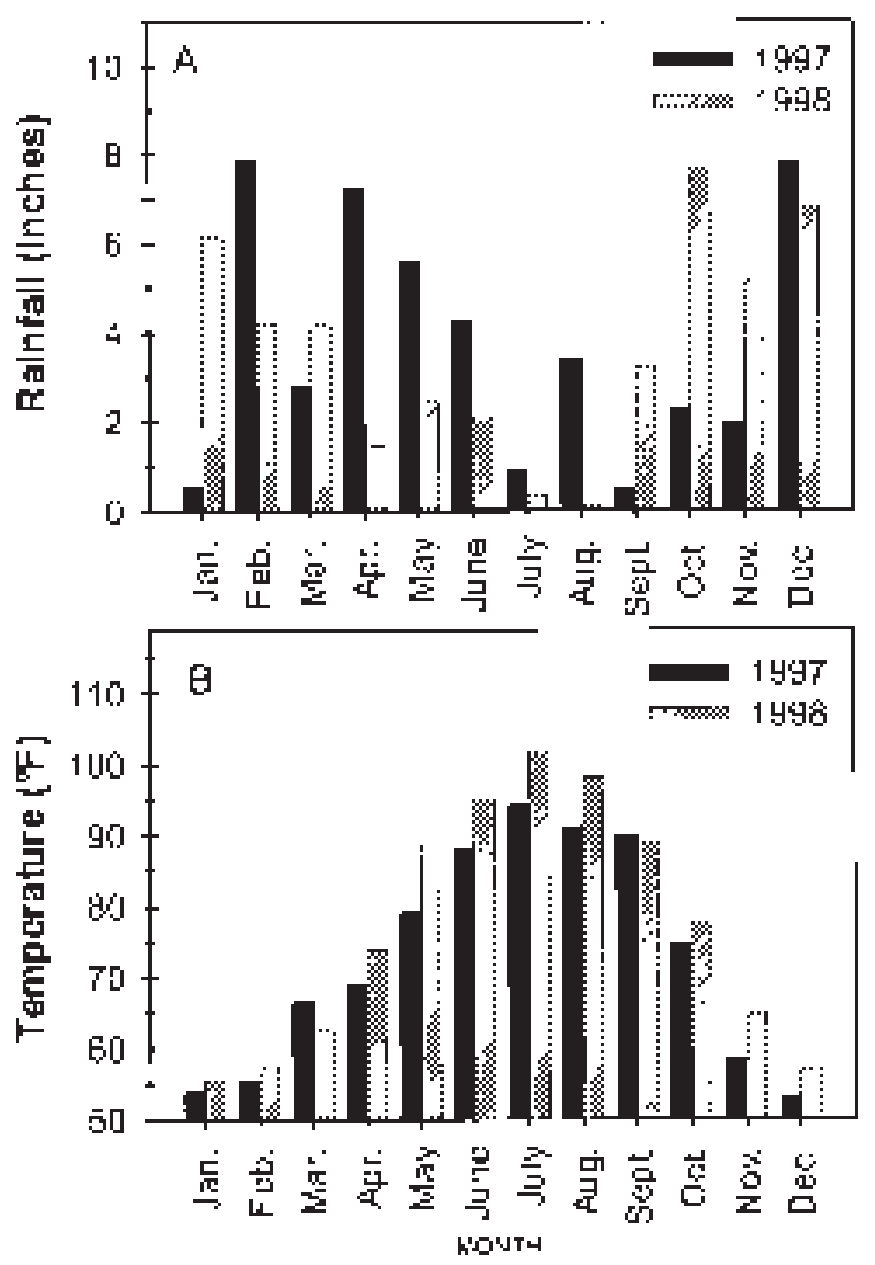

Fig. 1. Monthly rainfall totals $(A)$ and average monthly maximum temperatures (B) for 1997 and 1998; 1 inch $=25.4 \mathrm{~mm} ;{ }^{\circ} \mathrm{C}=1.8\left({ }^{\circ} \mathrm{F}\right)+32$. 


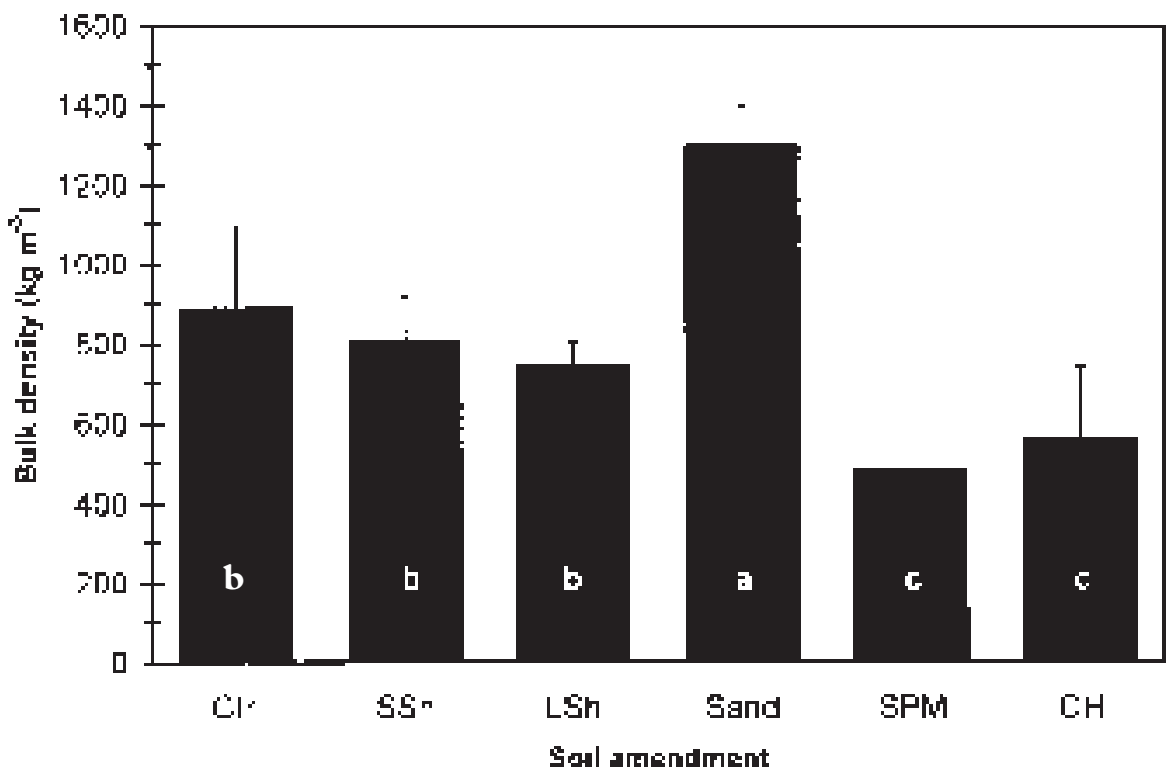

Fig. 2. Effect of 1 to $3 \mathrm{~mm}(0.039$ to 0.118 inches) small diameter expanded shale (SSh), 3 to $6 \mathrm{~mm}$ (0.118 to 0.354 inches) large diameter expanded shale (LSh), sand, sphagnum peatmoss (SPM), and cottonseed hulls (CH) on bulk density of Austin silty clay (Ctrl) soil 7 months after application. Columns with the same letter are not statistically different at $P=0.05, \mathrm{n}=6 ; 100 \mathrm{~kg} \cdot \mathrm{m}^{-3}=6.2$ $\mathbf{l b} / \mathbf{f t}^{3}$.

removed for quantification. For the second year, it was difficult to identify the original root ball, so the entire root weight, including the original root ball, was quantified. Therefore, root weights were generally larger the second year. Roots were dried at $60^{\circ} \mathrm{C}$ for $48 \mathrm{~h}$ before weighing.

Since our primary focus was on the effect of the inorganic ExSh amendments, we allowed the soil amendments to physically equilibrate with the soil for 7 months before measuring soil bulk density. Soil cores of known volume $[3$-inch diameter $\times 2$-inch depth $(7.6 \times 5.1-\mathrm{cm})]$ were extracted from the 2 - to 4 -inch $(5.1$ - to 10.2 $\mathrm{cm}$ ) depth of each plot using a hammer-driven cylindrical core sampler. The inner cylinder consisted of three consecutive 2 -inch sections. Soil was trimmed flush with the top and bottom of the middle cylinder section. Cores were dried at $105^{\circ} \mathrm{C}\left(221^{\circ} \mathrm{F}\right)$ for $48 \mathrm{~h}$ and then weighed. Bulk density was calculated as the oven dry soil weight divided by the cylinder volume (Blake and Hartge, 1986).

Data was analyzed using the Statistical Analysis Software (SAS Institute, 2001). For qualitative pansy and scaevola ratings, a univariate analysis showed that the data had a normal distribution. Therefore, data was analyzed by analysis of variance (ANOVA) with seasonal treatment means sepa- rated by Duncan's multiple range test (DMRT). Plant survival counts were transformed using an arcsine function before performing an ANOVA and separation of treatment means by DMRT. Soil bulk density, pansy yield, N content, and root weights were analyzed by an ANOVA with treatment means separated by DMRT.

\section{Results and discussion}

Growing conditions. Figure lA shows monthly rainfall distribution and average monthly maximum temperatures for 1997 and 1998 when this study was conducted. In north-central Texas, the pansy growing season generally corresponds to the period from October to May and the scaevola growing season from May to November. Rainfall during the first half of 1997 , which represents the bulk of the pansy growing season, was generally high. Rainfall during the same period of 1998 was more moderate. Rainfall during the latter half of each year, which corresponds to the scaevola growing season, tended to be sporadic. However, July and August 1998 were particularly dry and research plots required frequent irrigation.

Average monthly maximum temperatures were similar during both years (Fig. 1B), but in 1998, temperatures from May to August were consistently higher than in 1997. This period cor- responds to the end of the pansy growing season and the beginning of the scaevola growing season. In general, temperature was not a major factor during the 2-year study. For pansy growth, the 1997 growing season was wetter than 1998. For scaevola growth, no single year was more favorable for growth than the other.

SoIL BULK DENSITY. Bulk density is a good indicator of potential rooting problems due to overly compacted soil. Jones (1983) found that for claytextured soils, similar to the Austin silty clay from the present study, root activity of several crops was greatest at soil bulk densities in the range of 1100 to $1300 \mathrm{~kg} \cdot \mathrm{m}^{-3}\left(68.5\right.$ to $\left.81.0 \mathrm{lb} / \mathrm{ft}^{3}\right)$. Figure 2 shows the effect of soil amendments on bulk density of the Austin silty clay soil measured 7 months after application. Bulk density of the unamended clay soil (control) was approximately $900 \mathrm{~kg} \cdot \mathrm{m}^{-3}\left(56.1 \mathrm{lb} / \mathrm{ft}^{3}\right)$, which is typical for a recently tilled clay-textured soil (Logsdon et al., 1999; Logsdon and Cambardella, 2000). The small and large diameter ExSh treatments (SSh and LSh) had no significant effect on soil bulk density. Sphagnum peatmoss and $\mathrm{CH}$ both significantly decreased soil bulk density. The quartz sand treatment was the only amendment that increased bulk density of the clay soil. None of the measured bulk densities were high enough to present a barrier to root growth.

Plant survival. During the first growing season, pansy plant survival was at or near $100 \%$ for all treatments (Table 1). For the second growing season, plant survival for the control decreased to $71 \%$, but there were no significant differences between the control and amended plots. In regards to pansy survival, ExSh treatments performed the same as other soil amendments.

The effect of ExSh amendments, in particular LSh, on scaevola survival was more dramatic, especially during the first year after application (Table 1). Large diameter ExSh and $\mathrm{CH}$ significantly increased plant survival relative to the control during both growing seasons. Small diameter ExSh and SPM also significantly increased scaevola survival during the second growing season.

Plant quality. The primary function of ornamental plants is to be aesthetically pleasing. For flowering 
Table 1. Effect of soil amendments on survival of pansy and scaevola plants in a clay soil during two growing seasons.

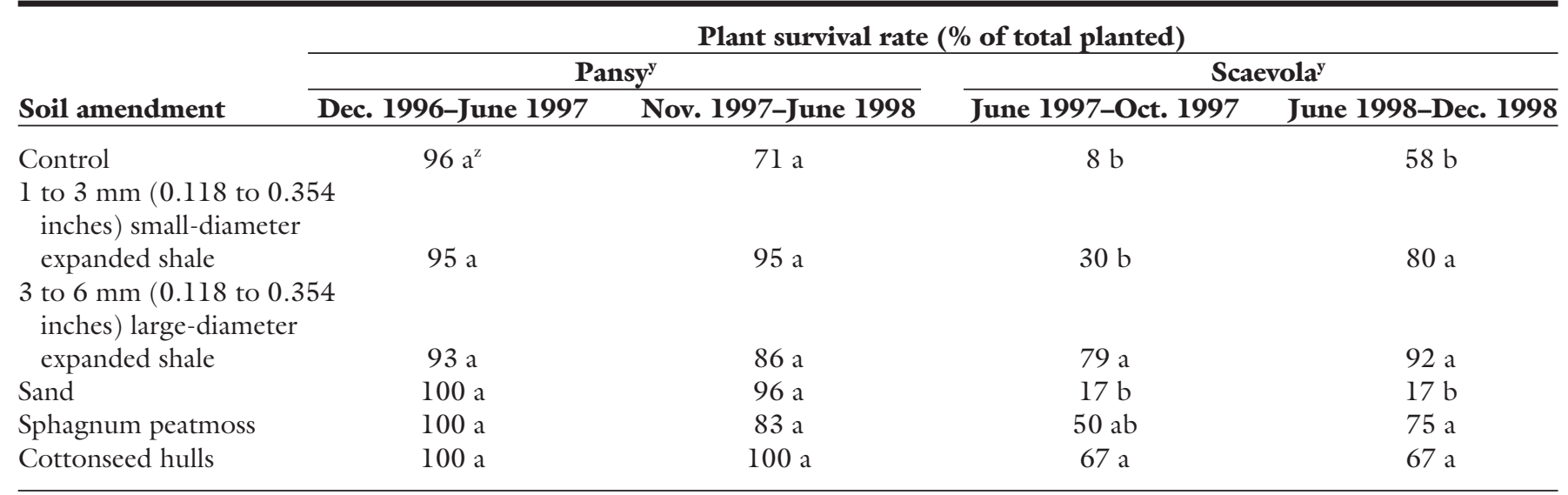

${ }^{\mathrm{z}}$ Means within a column followed by the same letter are not statistically different (Duncan's multiple range test, $P \leq 0.05$ ).

yalues represent survival of total pansies $(n=24)$ and scaevola $(n=12)$ planted.

annuals, this is primarily determined by the appearance of foliage and flowers. None of the soil amendments tested in this study had a major influence on pansy foliage quality relative to the unamended control (Fig. 3A), except for $\mathrm{CH}$, which significantly lowered pansy foliage quality during the 199697 growing season. During the 1996 97 growing season, SPM was the only amendment that had higher blossom ratings than the control (Fig. 3B). Large diameter ExSh had no effect on pansy foliage production and flowering, but SSh, sand, and $\mathrm{CH}$ actually decreased pansy foliage quality and number of blossoms relative to the control during the 1996-97 season. During the 1997-98 growing season, pansy foliage ratings and blossom numbers were nearly identical for the control and all soil amendments.

Soil amendments had an obvious beneficial effect on the quality of scaevola foliage and blossom coverage (Fig. 4). Large and small diameter

Fig. 3. Effect of 1 to $3 \mathrm{~mm}(0.039$ to 0.118 inches) small diameter expanded shale (SSh), 3 to $6 \mathrm{~mm}(0.118$ to 0.354 inches) large diameter expanded shale (LSh), sand, sphagnum peatmoss (SPM), and cottonseed hulls $(\mathrm{CH})$ on pansy foliage quality (A), number of blossoms per plant (B), pansy dry matter yield (C), pansy nitrogen content $(D)$, and root weight per plant (E) compared to a nonamended Austin silty clay soil (Ctrl) for two growing seasons. Columns within a growing season with the same letter are not statistically different (Duncan's multiple range test, $P \leq 0.05, \mathrm{n}=6$ ); $1 \mathrm{~g}=$ $0.035 \mathrm{oz} ; 1 \mathrm{~g} \cdot \mathrm{kg}^{-1}=0.1 \%$.

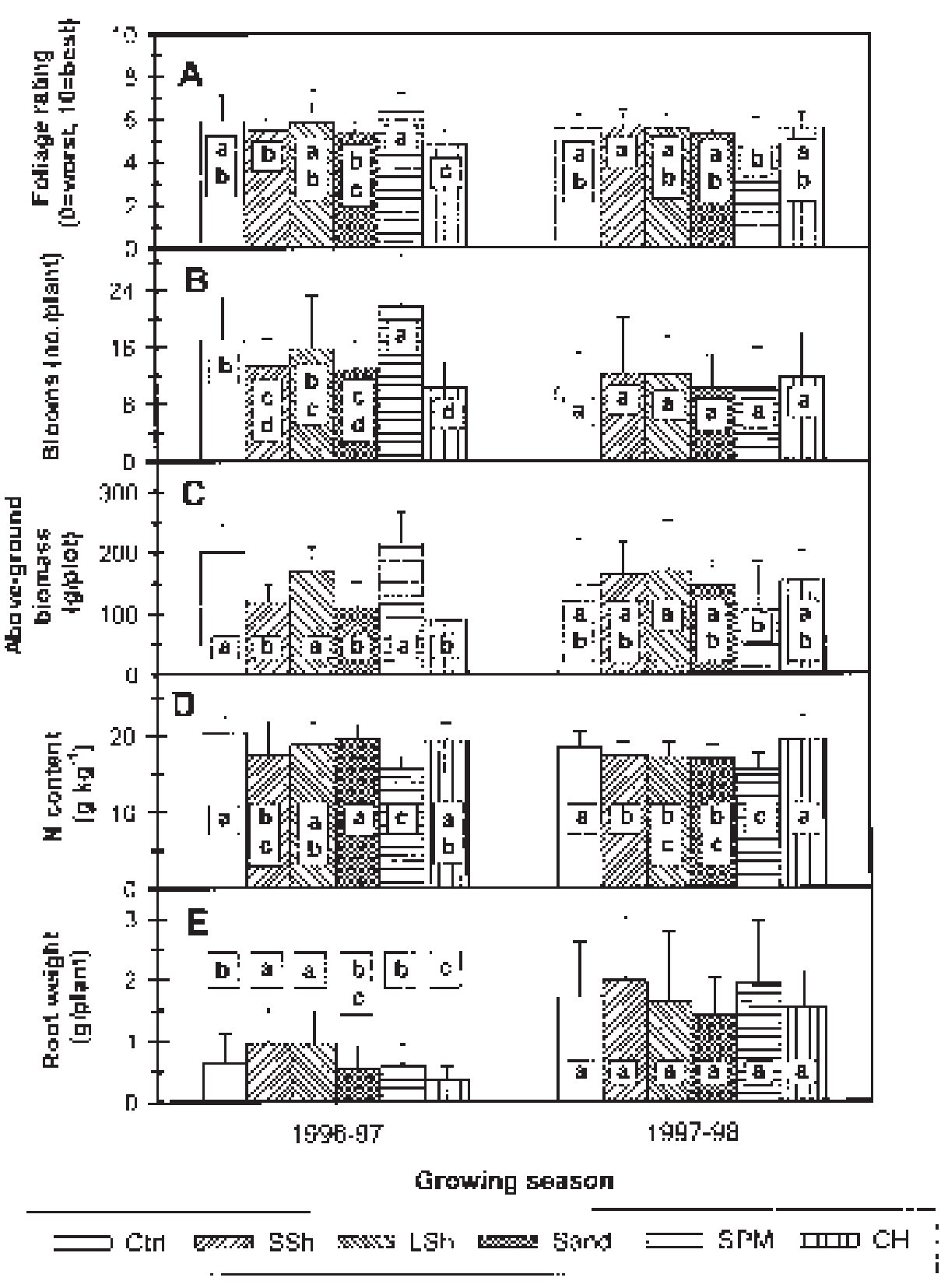




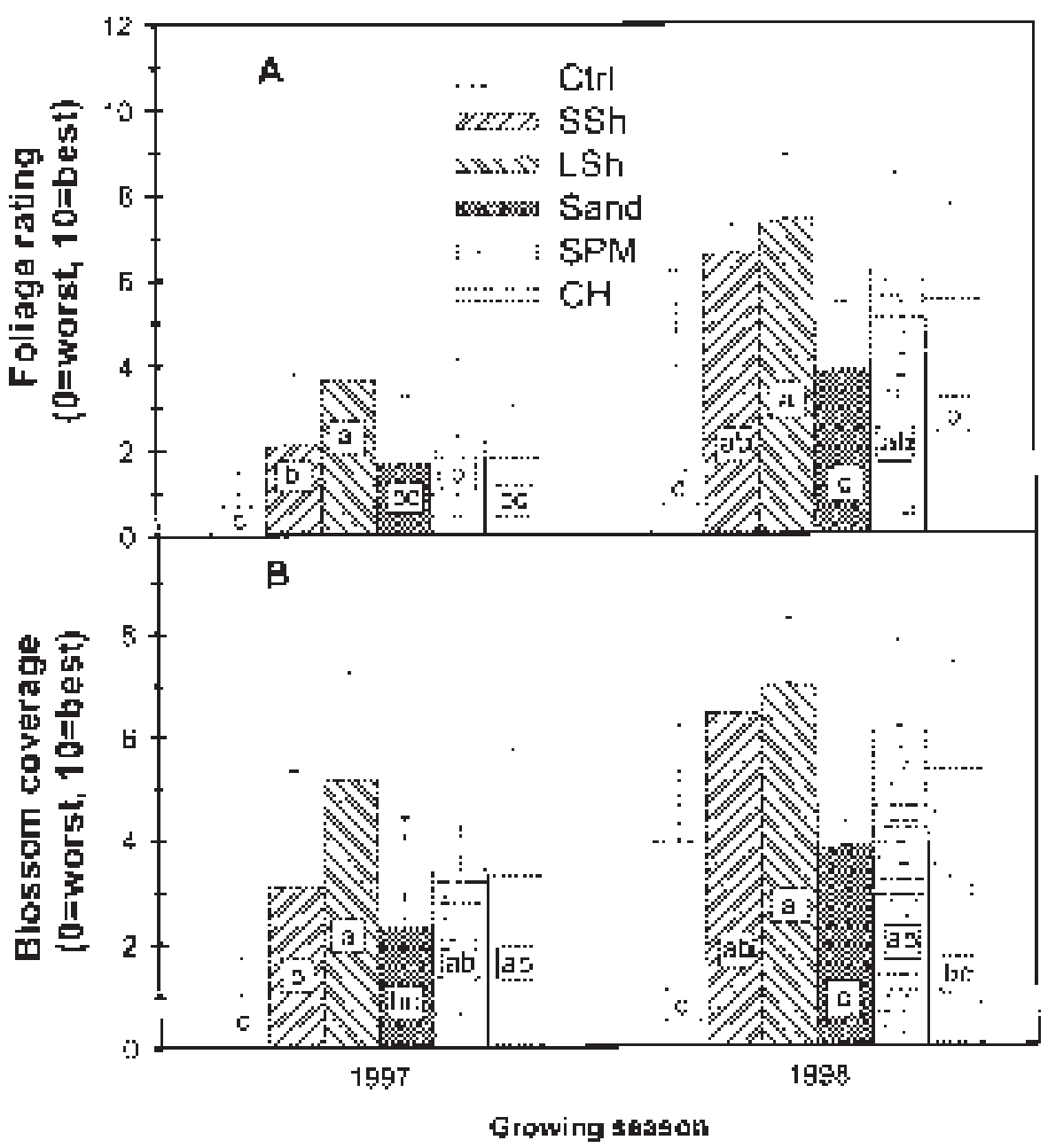

Fig. 4. Effect of 1 to $3 \mathrm{~mm}(0.039$ to 0.118 inches) small diameter expanded shale (SSh), 3 to $6 \mathrm{~mm}$ (0.118 to 0.354 inches) large diameter expanded shale (LSh), sand, sphagnum peatmoss (SPM), and cottonseed hulls (CH) on scaevola foliage quality (A) and blossom coverage (B) ratings in a clay soil (Ctrl) for two growing seasons. Columns within a growing season with the same letter are not statistically different (Duncan's multiple range test, $P \leq$ $0.05, n=6)$.

ExSh and SPM increased the quality of scaevola foliage (Fig. 4A) and extent of flowering (Fig. 4B) relative to the control during both the 1996-97 and 1997-98 growing seasons. Cottonseed hulls significantly increased scaevola foliage quality in 1998 (Fig. $4 \mathrm{~A}$ ) and scaevola blossom coverage in 1997 (Fig. 4B). Scaevola is a native Australian plant that grows better in well-drained containers than in poorly drained clay-textured soils (Steffen, 1989). It is likely that the ExSh and SPM amendments improved the scaevola rooting environment, which translated to improved above-ground growth. The improved rooting environment might be attributed to better soil aeration, more favorable soil moisture levels, or possibly, a combination of these factors.
Pansy yield AND NItRogen CONTENT. Total above-ground biomass production can be an indication of how soil amendments affect plant growth. Biomass data showed that the effects of soil amendments on pansy growth were either neutral or negative during the first year after application, but by the second year, no negative effects were observed (Fig. 3C). During the 1996-97 growing season, only LSh and SPM had dry matter yields equivalent to the control. All other amendments reduced dry matter yield relative to the control. The trend among treatments for 1996-97 is nearly identical to that for foliage ratings and blossom numbers (Fig. 3A and $\mathrm{B}$ ), which demonstrates that plant quality is closely allied to overall aboveground plant biomass. During the
1997-98 growing season, none of the soil amendments significantly affected dry matter yield compared to the control.

Cottonseed hulls was the only amendment that did not significantly decrease plant $\mathrm{N}$ content during either growing season (Fig. 3D). Large diameter ExSh and sand decreased plant $\mathrm{N}$ the second growing season, but not the first. Sphagnum peatmoss significantly decreased pansy $\mathrm{N}$ content during both growing seasons, probably due to immobilization of soil $\mathrm{N}$ by soil microorganisms after the addition of a readily available carbon source. Small diameter ExSh also decreased pansy N content during both seasons, but not as much as SPM during the 1997-98 growing season. For the most part, the soil amendments had no major influence on pansy $\mathrm{N}$ content. The $\mathrm{N}$ content for all treatments was near the lower limit of the range typically required for optimal plant growth (Marschner, 1986).

Pansy root weights. Pansy root data must be interpreted in light of the fact that data for the first year includes only roots extending beyond the original root ball whereas data for the second year includes the entire root weight. Therefore, we focus only on differences among treatments within each year and do not compare root weights between years. At the end of the 1996-97 season, pansy root weights for the SSh and LSh treatments were significantly greater than the control and all other soil amendments (Fig. 3E). Climatic data showed that rainfall from February to May during the 1996-97 pansy growing season [ 15.6 inches $(39.62 \mathrm{~cm})]$ was considerably higher than the same period during the 1997-98 growing season [ 8.1 inches $(20.57 \mathrm{~cm})]$. The Austin silty clay soil is poorly drained, so high amounts of precipitation can lead to periods of excessive soil moisture. High soil moisture reduces soil aeration, which may contribute to poor root development and increased root disease. It is possible that in the 199697 growing season, excess soil water drained more easily from soils amended with ExSh than from other soil amendments and this created a more favorable environment for the production and proper functioning of root tissue. Pansy root weights for the 1997-98 growing season were not significantly affected by soil amendments. Exces- 
sive soil moisture was probably not a problem during the 1997-98 growing season due to less rainfall.

The ability of soil amendments to improve plant performance depends on the type of plant and on prevailing weather conditions. Plants that have a low tolerance for poor soil aeration, such as scaevola, may perform better in soils amended with LSh (3 to $6 \mathrm{~mm}$ ) and SPM. Small diameter ExSh ( 1 to 3 $\mathrm{mm}$ ) had no consistent effect on pansy or scaevola growth. During periods of excessive rainfall, plant root growth in clay soils may be aided by the incorporation of LSh. Cottonseed hulls tended to decrease plant performance the first year they were applied, probably due to $\mathrm{N}$ immobilization induced by a high $\mathrm{C}$ to $\mathrm{N}$ ratio, but improved it the second season. In terms of overall plant performance, the positive responses from LSh were more consistent than the other amendments evaluated. However, in the short term ( 1 to 2 years ), a single application of SPM also produced positive responses in plant performance. Incorporation of LSh into soil is essentially a permanent modification of the soil's physical properties. It may be feasible to use this practice in highly visible and intensively utilized planting beds.

\section{Literature cited}

Baker, S.W. and P.M. Canaway. 1992. The effect of sand top dressing on the performance of winter games pitches of different construction types: play quality. J. Sports Turf Res. Inst. 68:62-72.

Bhalla, P.L. and K. Sweeney. 1998. Micropropagation of scaevola-Australian native of ornamental horticulture. Austral. J. Expt. Agr. 38:399-401.

Bigelow, C.A., D.C. Bowman, D.K. Cassel, and T.W. Rufty, Jr. 2001. Creeping bentgrass response to inorganic soil amendments and mechanically induced subsurface drainage and aeration. Crop Sci. 41:797-805.

Blake, G.R. and K.H. Hartge. 1986. Bulk density, p. 363-375. In: A. Klute (ed.). Methods of soil analysis: Part 1-Physical and mineralogical methods. $2^{\text {nd }}$ ed. Soil Sci. Soc. Amer. Book Ser. 5.
Bremner, J.M. 1996. Nitrogen-total, p.1085-1121. In: D.L. Sparks et al. (eds.). Methods of soil analysis. Part 3. Chemical methods. Soil Sci. Soc. Amer. Book Ser. 5.

Carlson, M.S. , C.L. Kerkman, and W.R. Kussow. 1998. Peats and supplements for root zone mixes. Golf Course Mgt. 66(9):70-74.

Dowdell, R.J., R. Crees, J.R. Burford, and R.Q. Cannell. 1979. Oxygen concentrations in a clay soil after ploughing or direct drilling. J. Soil Sci. 30:239-245.

Erickson, A.E. 1982. Tillage effects on soil aeration, p. 91-104. In: Predicting tillage effects on soil physical properties and processes. Amer. Soc. Agron. Spec. Publ. 44.

Fischer, P. 1990. Effect of $\mathrm{pH}$ value and phosphate surplus. Zierpflanzenbau 30:7678.

Fischer, P. 1991. Wirkamseit von Eisenchelaten. Deutscher Gartenbau. 13:816-819.

Gerlach,W.W.P. 1990. Verticillium-Welke als neue Krankheit an Scaevola. Gaertnerhoerse und Gartenwelt. 90:15281529.

Grable, A.R. and E.G. Siemer. 1968. Effect of bulk density, aggregate size, and soil water suction on oxygen diffusion redox potentials, and elongation of corn roots. Soil Sci. Soc. Amer. Proc. 32:180-186.

Hendrix, P.F., C.R. Han, and P.M. Groffman. 1988. Soil respiration and notillage agroecosystems under different winter cover crop rotations. Soil Till. Res. 12:135-148.

Hsu, J.T., D.B. Faulkner, K.A. Garleb, R.A. Barclay, G.C. Fahey, and L.L. Berger. 1987. Evaluation of corn fiber, cottonseed hulls, oat hulls and soybean hulls as roughage sources for ruminants. J. Animal Sci. 65(1):244-255

Huck, M.G. 1970. Variation in taproot elongation rate as influenced by composition of the soil air. Agron. J. 62:815-818.

Jayawardane, N.S. and W.S. Meyer. 1985. Measuring air-filled porosity changes in an irrigated swelling clay soil. Austral. J. Soil Res. 23:15-22.

Jones, C.A. 1983. Effect of soil texture on critical bulk densities for root growth. Soil Sci. Soc. Amer. J. 47:1208-1211.
Logsdon, S.D. and C.A. Cambardella. 2000. Depth-incremental soil properties under no-till or chisel management. Soil Sci. Soc. Amer. J. 63:197-200.

Logsdon, S.D., T.C. Kaspar, and C.A. Cambardella. 1999. Temporal changes in small depth-incremental soil bulk density. Soil Sci. Soc. Amer. J. 64:710-714.

Marschner, Horst. 1986. Mineral nutrition of higher plants. p. 213. Academic Press, San Diego, Calif.

McAfee, M., J. Lindstrom, and W. Johansson. 1989. Aeration changes after irrigation in a clay soil. J. Soil Sci. 40:719729.

Meek, B.D., C.F. Ehlig, L.H. Stolzy, and L.E. Graham. 1983. Furrow and trickle irrigation: Effects on soil oxygen and ethylene and tomato yield. Soil Sci. Soc. Amer. J. 47:631-635.

Puentes, R., B.L. Harris, and C. Victora. 1988. Management of vertisols of temperate regions, p. 129-130. In: L.P. Wilding and R. Puentes (eds.). Vertisols: Their distribution, properties, classification and management. Soil Mgt. Support Serv., Texas A\&M Univ. Printing Ctr., Tech. Monogr. 18.

Salisbury, F.B. and C.W. Ross. 1985. Plant physiology. $3^{\text {rd }}$ ed.p. 114-116. Wadsworth, Belmont, Calif.

SAS Institute, Inc. 2001. The SAS System for Windows. Release 8.02. SAS Institute, Inc., Cary, N.C.

Sloan, J.J., W. Mackay, and S. George. 2000. Growing mediums for porous pavement and rooftop gardens, p. 321-327. In: W. Burghardt and C. Dornauf (eds.). Proc. 1st Intl. Conf. Soils of Urban, Industrial, Traffic and Mining Areas. UniversitätGH Essen, Essen, Germany.

Steffen, K. 1989. A hanging basket plant with future-Scaevola aemula. Gaertnermeister 92:944-945.

U.S. GolfAssociation, Green Section Staff. 1993. Specifications for a method of putting green construction. USGA, Far Hills, N.J.

Voorhees, W.B., D.A. Farrell, and W.E. Larson. 1975. Soil strength and aeration effects on root elongation. Soil Sci. Soc. Amer. Proc. 39:948-953. 